\title{
THE CONCEPT OF CORPORATE GOVERNANCE
}

\author{
Manuel Alfonso Garzón Castrillón \\ FIDEE Research Group \\ Foundation for Research and Business Educational Development \\ Barranquilla, Colombia, South America \\ manuelalfonsogarzon@fidee.org
}

Reception date: 12/18/2020 - Revision date: 02/24/2021 - Approval date: 03/04/2021

DOI: https://doi.org/10.36995/i.visiondefuturo.2021.25.02R.005.en

\section{ABSTRACT}

This article aimed to identify the different concepts of corporate governance, in this sense, the first section presents a review of the literature based on the Methodi Ordinatio in relation to the concept of corporate governance (CG), followed by the revision of the theories from which it is studied: Theory of the agency; the shareholder or stockholder theory; the resource dependency theory; Stakeholder theory; the theory of Stewardship or Management Theory, the approach based on knowledge and corporate governance and the performance of the company, finally, the conclusion of the study in which it stands out that the objective of $C G$ theories is not to study how managers govern - that would lead us to confuse the term governance with administration - but rather how it is

KEY WORDS: Corporate governance; Theory.

\section{INTRODUCTION}

The practice of corporate governance (CG) in organizations has developed rapidly in recent times, and its importance has been highlighted around the world. It has even been adopted by countries that have not yet regulated the adoption of CG in their organizations. The reason for the global interest in GC is that it underpins a company's operating framework. Therefore, the adoption and implementation of the QA practice is expected to benefit the owners, since they are committed to using the principles and mechanisms, which in the broadest sense amounts to an effective monitoring of the activities of a company, particularly when the principles of disclosure and transparency are adopted. (Grantham, (2020).

Consequently, when adopting and implementing CG in companies, this decision can have a positive impact on decisions related to current investors, on the one hand, and potential investors on the other (Hebble and Ramaswamy, 2005). The bankruptcy and collapse of large US corporations such as Worldcom, Enron and Adolphia, and public awareness of these financial disasters has led investors to become increasingly aware of organizations that are known for having good QA practices to achieve and maintain a good reputation, since there is 
guidance for investors to prefer to invest in companies that adopt best QA practices In addition, as the information is available, shareholders and owners can access and evaluate decisions on a daily basis, in addition to the evaluation carried out by the analysts (Alabdullah, Yahya and Thurasamy 2014).

In this way, the clear and important role of the CG is highlighted with respect to the effect of these mechanisms on the performance of companies (Alabdullah, 2016). Several studies prove the relationship between CG and company performance, but the results are inconsistent; some report positive results, and others are mixed: negative and positive from company performance (Alabdullah et al., 2016).

This article fills a gap in relation to the concept of corporate governance, in this sense, the first section presents a review of the literature in relation to the concept of corporate governance (CG), followed by a review of the theories from which It is studied: Theory of the agency; Theory of the shareholder or stockholder; The resource dependency theory; the Stakeholder Theory; Stewardship Theory or Management Theory, an approach based on knowledge and corporate governance and the performance of the company and finally, the conclusion of the study.

\section{DEVELOPMENT}

\section{Methodology}

In the present investigation, the methodology called Methodi Ordinatio de Pagani was used; Kovaleski; and Resende, (2015); based on which the stages proposed by the authors were developed, which include conducting a preliminary exploratory research with keywords in databases, the combination of keywords used were: Corporate governance; practice of corporate governance; Impact of Corporate Governance; Characteristics on Corporate; Corporate Governance and control, Corporate governance theory, fundamental theories in corporate governance and the databases consulted Scopus, WoS, and Scielo; the final search in the databases, the filtering procedure, was carried out taking into account the identification of the impact factor, year of publication and number of citations.

The classification of the works using the formula of the InOrdinatio de Paganiet.al. (2015);

InOrditnatio $=\left(\right.$ IF / 1000) $\alpha^{*}[10-($ Research year - year of publication $)]+(\Sigma C i)$, where: (Pagani et.al (2015)

- IF is the impact factor, $a$ is a weighting factor ranging from 1 to 10 , which must be attributed by the researcher;

- ResearchYear is the year in which the research was developed;

\footnotetext{
"Visión de Futuro" Año 18, Volumen N²5 N², Julio - Diciembre 2021 - Pág 178 - 194

URL de la Revista: http://visiondefuturo.fce.unam.edu.ar/index.php/visiondefuturo/index

URL del Documento: https://visiondefuturo.fce.unam.edu.ar/index.php/visiondefuturo/issue/view/21

ISSN 1668 - 8708 - Versión en Línea

E-mail: revistacientifica@fce.unam.edu.ar
} 
- PublishYear is the year the article was published; and

- Summation $\mathrm{Ci}(\Sigma \mathrm{Ci})$ is the number of times the article was cited.

Based on the results obtained, the articles were classified, the complete documents were searched, and the final reading and systematic analysis of the papers were read.

\section{Definitions of Corporate Governance}

Definitions of corporate governance vary considerably (Claessens, 2003). These definitions correspond to approximations made since 1992 focused on establishing guidelines for the management and control of companies, directing their actions to guarantee investors that their invested resources are investors that the resources they provide are managed to achieve profitability and efficiency.

Based on the authors consulted, Table 1 was prepared:

Table 1. Emphasis on corporate governance models

\begin{tabular}{|c|l|l|}
\hline No & \multicolumn{1}{|c|}{ Emphasis } & \multicolumn{1}{c|}{ Autors } \\
\hline 1 & Government Financial Model & $\begin{array}{l}\text { La Porta, Lopez-de-Silanes, Shleifer and Vishny } \\
(2000) \text {; Zingales (2014); Hilb (2005); Chisari and } \\
\text { Ferro (2009); Andrés-Alonso and Santamaría- } \\
\text { Mariscal (2010); OCDE (2004) }\end{array}$ \\
\hline 2 & $\begin{array}{l}\text { Governance Model of Contracts } \\
\text { between Participants } \\
\text { (Normative) }\end{array}$ & $\begin{array}{l}\text { Claessens, 2003; Weil, Gotshal \& Manges LLP } \\
(2012), \text { Petrică (2012); Andrés-Alonso and } \\
\text { Santamaría-Mariscal (2010); OCDE (2004) }\end{array}$ \\
\hline 3 & Cognitive Government Model & $\begin{array}{l}\text { Lefort y Walker (2003); Wigodski and } \\
\text { Zuñiga(2003), Petrică (2012); Claessens, 2003 } \\
\text { Andrés-Alonso and Santamaría-Mariscal (2010); } \\
\text { OCDE (2004) }\end{array}$ \\
\hline 4 & Decision making & $\begin{array}{l}\text { Denis and McConnell (2003); Andrés-Alonso and } \\
\text { Santamaría-Mariscal (2010); OCDE (2004) }\end{array}$ \\
\hline 5 & Good practices & $\begin{array}{l}\text { Center of Excellence in Corporate Governance, } \\
\text { (2009:4); OCDE (2004) }\end{array}$ \\
\hline
\end{tabular}

Source: Prepared based on the authors cited in this table

From table 1 it can be deduced that the emphasis of the analyzed authors in relation to CG is on the following components: a government financial model; that of a model of governance of contracts between participants (normative); a cognitive model of government; or focused on decision-making through good practices that for Andrés-Alonso and SantamaríaMariscal (2010) should be focused on governance mechanisms that discipline managers and resolve agency conflicts, or on governance mechanisms that induce learning and, for example, that stimulate managers to imagine, perceive and generate new investment opportunities.

But the proposal made by Paz-Ares (2004) makes a distinction of corporate governance depending on whether it is imposed on the company or voluntarily assumed. It calls external or institutional corporate governance (imposed from outside by the legal system and the network of institutions of a given country) and internal or contractual corporate governance

\footnotetext{
"Visión de Futuro" Año 18, Volumen No 25 N², Julio - Diciembre 2021 - Pág 178 - 194

URL de la Revista: http://visiondefuturo.fce.unam.edu.ar/index.php/visiondefuturo/index

URL del Documento: https://visiondefuturo.fce.unam.edu.ar/index.php/visiondefuturo/issue/view/21

ISSN 1668 - 8708 - Versión en Línea

E-mail: revistacientifica@fce.unam.edu.ar
} 
(voluntarily assumed from within by each company). Allayannis, Lel, and Miller (2012) make a similar distinction in a study on the reasons for holding foreign exchange derivatives, referring to corporate governance at the country level and corporate governance at the company level.

Based on the revised definitions, it is concluded that the ultimate purpose of the good governance of the company is to add value to it, and to ensure that those who contribute directly or indirectly to its generation can participate in the increase in value. For this reason, good practices establish conditions to protect and equitably reward shareholders for the capital contributed; to reward workers for their work and intellectual contribution; to offer customers higher quality products and services and better prices; to adequately remunerate suppliers for the delivery of products or the provision of services and to offer them guarantees or the confidence that they will be paid in a timely manner; to offer creditors that the resources they have lent to the company will be restored and that they will be well compensated; it also includes responsibility towards society in general, thus including compliance with tax obligations.

In this regard, it is necessary to establish that there is no distinctive definition that specifically describes the meaning of CG when taking into account the integral characteristics of the CG system, therefore, there is some controversy and confusion regarding the definition of CG (Windsor, 2009). However, in general, the traditional definition of CG is the one proposed by the Organization for Economic Cooperation and Development (OECD, April 1999) which provided the following: Corporate governance is the system by which business corporations are directed and controlled. (OECD, 2016)

Depending on the point of view with which the definition of corporate governance of companies is faced, they can have different meanings. From an economic perspective, corporate governance is generally understood as defending the interests of shareholders (García, 2014)

Finally, the concept of corporate governance is explained by the authors, and not expressly defined because it encompasses different areas of interaction, such as management, ethical, legal, regulatory, structural, and behavioral aspects. The approach adopted, whether of the shareholder or the stakeholder, will determine the type of corporate governance that will be developed in a company, or in a country and the mechanisms through which its compliance will be verified. Corporate governance is a process, not a state. The field is continually evolving (Claessens, 2003).

\footnotetext{
"Visión de Futuro" Año 18, Volumen No 25 N² 2, Julio - Diciembre 2021 - Pág 178 - 194

URL de la Revista: http://visiondefuturo.fce.unam.edu.ar/index.php/visiondefuturo/index

URL del Documento: https://visiondefuturo.fce.unam.edu.ar/index.php/visiondefuturo/issue/view/21

ISSN 1668 - 8708 - Versión en Línea

E-mail: revistacientifica@fce.unam.edu.ar
} 


\section{Good governance codes}

It is also important to bear in mind that the concept of corporate governance is framed within business ethics. Business ethics is the ethics applied to the organizational field, which refers to human quality, the excellence of people and their actions, within the framework of their work in them. Good business conduct practices are embodied in codes of ethics, which contemplate the set of values that are established in the same system or code in order to benefit the company as a whole. Thus, corporate governance framed within the area of business ethics is defined as the system by which companies are directed and controlled, Cadbury (1992) and embodied in the so-called codes of good governance.

In this way, the objective of all good governance codes is to protect shareholders from the power of managers, as well as to ensure that there is good control of the former towards the latter, avoiding the agency problems existing between them. In this context, it is agency theory that studies the relationships between shareholders and managers and the underlying conflicts of interest between the two. Currently, there are various control mechanisms, both externally (goods and services market, capital market, job market for managers and corporate control market) and internal (board of directors, design of compensation contracts, general meeting of shareholders and financial structure). All of them aim to reduce existing agency problems, such as opportunistic and self-interested profit-making by managers.

In order to reconcile the common objectives between the shareholders (principal) and the managers (agents), the figure of the board of directors appears. It is a key entity within the internal mechanisms used by companies to control their executives (Dalton, Daily, Ellstrand and Johnson, 1998). The directors belonging to the boards of directors will have a level of information about the composition and characteristics of said boards in matters of corporate governance.

Depending on a series of characteristics of the board, a level of corporate governance culture is determined, in which, at a higher level of corporate culture, fewer agency problems between shareholders and company executives. In fact, existing agency problems in a company can be minimized. On the one hand, through the control of internal mechanisms such as those related to the composition of the board of directors (Baek, 2009) and, on the other, favoring the transparency of organizations, through the issuance of more adequate financialaccounting information to reality (Fernández-Rodríguez, Gómez-Ansón and Cuervo-García, 2008).

The issuance of good governance codes by different countries improves the level of corporate governance culture by companies (Zattoni and Coumo, 2008), which favors obtaining better business results (Alix Valenti, Luce and Mayfield , 2011). This is achieved

\footnotetext{
"Visión de Futuro" Año 18, Volumen No 25 N², Julio - Diciembre 2021 - Pág 178 - 194

URL de la Revista: http://visiondefuturo.fce.unam.edu.ar/index.php/visiondefuturo/index

URL del Documento: https://visiondefuturo.fce.unam.edu.ar/index.php/visiondefuturo/issue/view/21

ISSN 1668 - 8708 - Versión en Línea

E-mail: revistacientifica@fce.unam.edu.ar
} 
through comply or explain recommendations, which dictate procedures that favor the disclosure of more and better information for all the agents involved (Van den Berghe, 2002; Monks and Minow, 2004). By obtaining better results, on the one hand, and information more appropriate to the reality of the company on the other, the ultimate goal of value creation companies is achieved.

The ethical standards and regulatory provisions included in the Corporate Governance reports are essential to avoid tensions between managers and company owners. These are the so-called agency problems, developed in agency theory by Jensen and Meckling (1976). This theory was later expanded by Tosi and Gomez-Mejia (1994). The agency theory is the most used to date to justify the relationships between the company and its interest groups (Hermalin, Weisbach, 2000) compared to the rest of the existing theories (Jensen and Meckling 1976; Eisenhardt, 1989).

Corporate Governance is embodied in specific codes developed by each of the different countries ${ }^{1}$. Until now, it has not been possible to create a single international code that is capable of providing general enough recommendations to encompass the different Corporate Governance policies in different cultures.

\section{Structure of corporate governance}

The corporate governance structure specifies the distribution of rights and responsibilities among the different participants in the corporation, such as the board, managers, shareholders and other interested parties, and details the rules and procedures for making decisions on corporate matters (Hebble and Ramaswamy , 2005). Additionally, other definitions of GC can be found in the body of existing literature. For example, GC is a system that aims to provide control and direction to organizations as described by Cadbury (1992); They provided another definition: GC is a process in which the Financiers of an organization expect to obtain a return on their investment.

\section{Principles of Corporate Governance}

Since 1999, the Organization for Economic Cooperation and Development (OECD) issued its Principles of Corporate Governance (OECD, 2004). These have become reference documents for policy makers, investors, corporations and other interest groups (stakeholders) around the world, who have increased the agenda and provide a specialized guide to good practices for their implementation that can be adapted to the particular circumstances of each

\footnotetext{
${ }^{1}$ Watch http://www.ecgi.org/codes/all_codes.php

"Visión de Futuro" Año 18, Volumen No 25 No 2, Julio - Diciembre 2021 - Pág 178 - 194

URL de la Revista: http://visiondefuturo.fce.unam.edu.ar/index.php/visiondefuturo/index

URL del Documento: https://visiondefuturo.fce.unam.edu.ar/index.php/visiondefuturo/issue/view/21

ISSN 1668 - 8708 - Versión en Línea

E-mail: revistacientifica@fce.unam.edu.ar
} 
country (members or non-members of the OECD) or region, whether for legislative and / or regulatory initiatives in member and non-member countries. Such principles can be summarized with the following postulates: OECD, (2004)

- Protect the rights of shareholders and ensure equitable treatment for all of them (minority and foreigners).

- Have the opportunity (all shareholders) to obtain an effective compensation for damages for the violation of their rights.

- Recognize the rights of interested third parties and promote active cooperation between them and societies in the creation of wealth, the generation of jobs and the achievement of sustainable financial enterprises.

- Be informed adequately and on time of all the relevant matters of the company (financial situation, performance, shareholding and its administration).

- Have a strategic guide for the company, effective monitoring of management by the Board of Directors (hereinafter CA, which in some countries would be the same JD) and its responsibilities with its shareholders.

Regarding the first principle mentioned above, when the $C G$ architecture establishes as a central point the effective protection of the interests of investors outside the company, they will be willing to pay more for corporate stocks and bonds, encouraging companies to issue these instruments to finance new projects (La Porta, et al., 2000).

Those countries that present a high degree of shareholder protection observe higher value stock markets, there are more companies traded, and there is a higher frequency of initial share offerings (La Porta, et al., 1998). Due to this, corporate governance also provides the means through which the company establishes its objectives, the mechanisms to achieve them and the monitoring of its performance (González, 2002).

The CG not only ensures the capital of the investors, but when it is applied properly it offers a set of conditions that guarantee to all the stakeholders that they will be able to recover their investment, plus some remuneration for it, whether they are owners or collaborators (workers) or other actors. (Lefort, 2003). In the case of proprietary constituents, also be able to give them access to the right to participate in the control of the corporation.

Currently there are more than eighty-two countries that have developed and published recommendations specific to the characteristics of their country. In addition, the issuers are different depending on each country, namely: the stock exchanges (when the initiative comes from the governing body of the stock market: SEC, CNMV, etc.), the government (when the issuer is the government of the nation or one of its ministries: Olivencia Report in Spain, for example), associations of directors (such as the Japan Corporate Governance Committee), 
associations of directors (Institute of Directors - Proudly in the Republic of South Africa or Comissão de Valores Mobiliários in Brazil), professional associations (Hong Kong Society of Accountants) or investor associations (Investment and Financial Services Association Limited - Blue Book in Australia).

However, despite all these international regulations, the problem of financial crises has not changed its trend. What is wrong? Why don't other countries take the step of turning their codes into laws? One of the possible answers is found in the legal tradition of each country. There are many investigations carried out on this subject. La Porta et al. (2000) argue that good governance codes are conditioned by the legal and institutional environment of each country and by the legal protection that investors enjoy and analyze their differences (Taliento, 2007).

The aim is to provide better protection to company investors in those nations where they have less legal coverage. Countries within the common law or Anglo-Saxon environment (common law countries) offer better legal protection than countries with a civil legal tradition (code law countries) (La Porta et al. 1998; La Porta et al. 2000). For this reason, the latter include a greater number of good governance measures than those corresponding to common law countries (Zattoni and Cuomo, 2008). It is clear that the more recently drafted codes seek greater investor coverage than the pioneer codes.

\section{Theories that study CG}

\section{The agency theory}

In 1776, Adam Smith exposed the agency problem, noting that managers of other people's money do not take the same care as the owner himself. Later in 1932, Berle and Means highlighted the existing separation between ownership and control of the company and its consequences (diversification of investment, low concentration of ownership), as well as the divergent interests between directors, managers and proprietary investors. In the same sense, Jensen and Meckling (1976) defined an agency relationship and how the principal can limit the divergences with respect to his interests by establishing appropriate incentives for the agent. Agency problems are controlled through decision systems (decision processes) that separate management decisions (implementation and application) and control decisions (ratification and monitoring) at all organizational levels (Fama and Jensen, 1983). This theory focuses on: information asymmetry, adverse selection and pre-contractual opportunism and moral hazard or post-contractual opportunism (Van-Slyke, 2006). This theory is the most used in corporate governance research and shows a continuous increase (Huang and Ho, 2011).

\footnotetext{
"Visión de Futuro" Año 18, Volumen No 25 N², Julio - Diciembre 2021 - Pág 178 - 194

URL de la Revista: http://visiondefuturo.fce.unam.edu.ar/index.php/visiondefuturo/index

URL del Documento: https://visiondefuturo.fce.unam.edu.ar/index.php/visiondefuturo/issue/view/21

ISSN 1668 - 8708 - Versión en Línea

E-mail: revistacientifica@fce.unam.edu.ar
} 
The initial analysis related to the opening of capital of the entrepreneurial company, in this model originated in an analysis by Jensen and Meckling (1976) that focused on two objectives. The first objective was to propose a contractual theory of the firm seen as a team of productive inputs (Alchian and Demsetz, 1972), inspired by the theory of property rights and focusing on the concept of the agency relationship. The second objective was to illustrate the explanatory power of this theory with respect to the problem of the capital structure of the company.

At first, Jensen and Meckling (1976) considered the company as a nexus of contracts, associating the company and the entire group of resource contributors (the input team ...), their limited objective of explaining the capital structure led them to build a more simplified model taking into account only two agency relationships. The first linked the manager to the shareholders and the second linked the company (represented by the administrators and shareholders) to the financial creditors. This initial modeling, which gave priority to the analysis of the relationship between the manager-entrepreneur who opens his capital and the new shareholders who played the role of principal and the administrator the agent, whose approach to the shareholder still dominates the research and normative reflections in the actuality.

The theory offers insight to explain the phenomena of corporate governance, particularly the agency-principle problems of conflicts between external investors and managers and the expropriation of minority shareholders by controlling shareholders (Eisenhard, 1989). The main contributions of agency theory to thinking about and reforming corporate governance are the ideas of risk, uncertainty of results, incentives and information systems. The study of conjectures that applies agency theory to corporate governance issues continues to grow, because it frequently tries to explain real events that occur in the world.

Finally, agency theory represents one of the most serious attempts to formulate a general theory of the firm in the framework of social relations (Jensen and Meckling 1976). These authors define the agency relationship as a contract under which one or more people ("principal") hire another person ("agent") to perform some service for the benefit of the principal, which means delegating authority over the agent. decision making. The approach that supports this theory is associated with the so-called agency costs: the "agents", directors or managers of the companies, may be tempted to act for their own benefit and make management decisions driven by their own interests. In any case, the agency theory has been the most applied in corporate governance research (Tricker, 2009).

\footnotetext{
"Visión de Futuro" Año 18, Volumen No 25 N², Julio - Diciembre 2021 - Pág 178 - 194

URL de la Revista: http://visiondefuturo.fce.unam.edu.ar/index.php/visiondefuturo/index

URL del Documento: https://visiondefuturo.fce.unam.edu.ar/index.php/visiondefuturo/issue/view/21

ISSN 1668 - 8708 - Versión en Línea

E-mail: revistacientifica@fce.unam.edu.ar
} 


\section{The resource dependency theory}

To explain corporate governance, the resource dependency theory is also used in some academic papers (Pfeffer and Salancik 1978). This theory interprets organizations as interdependent with the context in which they operate. Organizations will depend, to ensure their survival, on the resources and information provided by other companies and the agents of the context in which they are immersed. In these circumstances, organizations compete with other entities that use those same scarce resources.

These theories are limited to analyzing the relationships between partners, professional managers, the governing council and the environment, establishing the most important aspects of corporate governance, but do not take into account other interest groups such as customers, workers, business associations, and / or suppliers, among others. Thus arises the theory of stakeholders (Freeman, 1984) which considers that organizations should be responsible to a set of interest groups in the company and not only concern themselves with shareholders, since all these groups can affect the achievement of objectives. objectives of the organization and, consequently, the achievement of business success. it is necessary to apply agency theory. This is because the differences between shareholders and executives could be reduced through the existence of more efficient boards of directors.

\section{Shareholder or stockholder theory}

Is Friedman (1962) in the book Capitalism and Freedom, expresses that the only social responsibility of companies is to use resources in the development of activities that increase profits, obviously within the rules of free enterprise. The companies do not have moral obligations or social responsibilities with others that are not the shareholders, it is sought to maximize the profit for them.

In the shareholder approach, it is considered that the shareholders are the only ones with the right to participate in the income created by the company, therefore, in this case the value created is measured by what they receive.

This approach implies that corporate governance is oriented to the relationship between shareholders and managers who control and manage the creation of value, and only the interests of shareholders are taken into account. The goal of management is to maximize shareholder value.

\section{The Stakeholders approach}

The basis of this theory is attributed to Edward Freeman (1984), and he postulates that the organization must be developed taking into account the interests of the interest groups

\footnotetext{
"Visión de Futuro" Año 18, Volumen No 25 N² 2, Julio - Diciembre 2021 - Pág 178 - 194

URL de la Revista: http://visiondefuturo.fce.unam.edu.ar/index.php/visiondefuturo/index

URL del Documento: https://visiondefuturo.fce.unam.edu.ar/index.php/visiondefuturo/issue/view/21

ISSN 1668 - 8708 - Versión en Línea

E-mail: revistacientifica@fce.unam.edu.ar
} 
(employees, clients, suppliers and creditors) without contradicting the ethical principles on which the organization is based. capitalism, which is criticized by Mansell (2013) who argues that stakeholder theory undermines the principles on which the market economy is based by applying the concept of social contract to the organization. The legitimate claim on the signature is established through the existence of an exchange relationship. Stakeholders include shareholders, creditors, managers, employees, customers, suppliers, local communities, and the general public (Hill and Jones, 1992). Stakeholders are any group or individual that can affect or be affected by the achievement of the company's objectives (Freeman, 1984).

The stakeholder approach considers that all participants in the creation of value have the right to participate in the value that is added in the development of the value chain. This approach implies that corporate governance is oriented to safeguard and manage that the remuneration of all participants occurs, taking into account their opportunity cost. The interests of all participants and stakeholders in the company who are affected by the decisions and actions that occur in it, as well as their participation in corporate governance, are considered. The company is a nexus of contracts between the different stakeholders-shareholders, but also with creditors, employees, administrators, clients, suppliers, authorities, others, or an agreement according to which the company constitutes a cooperative game between the different stakeholders (Aoki, 1991).

In the stakeholder approach, corporate governance is affected by the relationships between the agents that intervene in the corporate governance system. As the OECD (2004) points out, these relationships are subject, in part, to laws and regulations, but also to voluntary adaptation and, more importantly, to market forces.

\section{The knowledge-based approach}

The process of creating value through the emergence of the investment opportunity set, which, in particular, is still neglected. To understand this process, we must turn to theories based on the knowledge of the company. In this approach, the creation of value depends mainly on the identity and skills of the company, seen as a coherent entity (Teece et al, 1994). Its specificity is linked to its ability to generate knowledge and, therefore, to its long-term profitability, while maintaining a dynamic concept of efficiency, knowledge-based theories include numerous perspectives that favor knowledge-based arguments. Three main perspectives can be identified: a) The behavioral perspective introduced by Cyert and March (1963): the firm is a political coalition and a cognitive institution that adapts itself through organizational learning. b) Neo-Schumpeterian evolutionary economic theory developed

\footnotetext{
“Visión de Futuro" Año 18, Volumen No 25 N², Julio - Diciembre 2021 - Pág 178 - 194

URL de la Revista: http://visiondefuturo.fce.unam.edu.ar/index.php/visiondefuturo/index

URL del Documento: https://visiondefuturo.fce.unam.edu.ar/index.php/visiondefuturo/issue/view/21

ISSN 1668 - 8708 - Versión en Línea

E-mail: revistacientifica@fce.unam.edu.ar
} 
mainly by Nelson and Winter (1982), which gave rise to a very important line of research. The firm is defined as an entity that coherently unites activities, a repository of productive knowledge (Winter, 1988), an interpretive system (Loasby, 2001), which favors the concept that competition is based on innovation. This theory replaces, in particular, the representation of investment options as a pre-existing menu with a conception in which the menu is built from knowledge acquired by learning and stored in organizational routines. c) Strategic theories based on resources and capabilities (the Resource-based View - RBV) that results mainly from the theory of the growth of the company proposed by Penrose (1959). The company appears to be a set of resources and a knowledge accumulation entity guided by the vision of the managers and based on the experience they have acquired. The origin of sustainable growth lies in the ability to learn and in the specificity of the accumulated stock of knowledge. This theory is at the origin of an extensive current of research that considers the knowledge-based theory of the company in strictus sensus the knowledge-based view.

In summary, the company, when seen as a processor or repository of knowledge, is based on the following applications of knowledge: (1) orientation of the activity according to the opinion of the administrators; (2) the creation of knowledge as a basis for innovation and all investment opportunities, this knowledge is tacit and social whose character makes it difficult to imitate; (3) protection of the knowledge database; (4) the coordination of the productive activity that involves aspects such as construction, exploitation and transfer of knowledge that go beyond the simple transfer of information. (Hodgson, 1998); and (5) conflict resolution, which goes beyond conflicts of interest to be taken in a knowledge-based aspect.

The company's knowledge-based approach leads to a reconsideration of the role of corporate governance. This should support the identification and implementation of profitable investments within a dynamic efficiency perspective. According to Demsetz, (1969), to understand the influence of the institutional framework and therefore of the QA system, in efficient dynamics, one must strive to balance three objectives: (1) a wide multiplicity of experimentation must be encouraged; (2) investment should be channeled into promising varieties of experimentation and away from unpromising opportunities; (3) the new knowledge that is acquired must be used extensively.

Prahalad's (1994) critique of the CG financial vision supports this approach: this vision should be broadened to consider the quality of the relationship between managers and investors and its potential to increase the efficiency of the company, to identify and generate growth opportunities. In a broad perspective, the knowledge-based approach results in the study of the systems of their influence on the different cognitive aspects of the value creation process.

\footnotetext{
"Visión de Futuro" Año 18, Volumen N$^{0} 25$ N² 2, Julio - Diciembre 2021 - Pág 178 - 194

URL de la Revista: http://visiondefuturo.fce.unam.edu.ar/index.php/visiondefuturo/index

URL del Documento: https://visiondefuturo.fce.unam.edu.ar/index.php/visiondefuturo/issue/view/21

ISSN 1668 - 8708 - Versión en Línea

E-mail: revistacientifica@fce.unam.edu.ar
} 
The knowledge-based approach also implies a reconsideration of the financial approach to corporate governance, in which the relationship between the company and investors is limited to the contribution of capital and where the sole objective is to secure financial investment by disciplining the best possible the managers. Therefore, as suggested by several authors, finance also includes a cognitive aspect. Consequently, Aoki, (1991) believes that, in the CG model associated with venture capital, it is not the ability of the venture capital investor to contribute funds that is the most important factor, but its ability, based on its knowledge and experience, to select the most promising projects and reject the financing (or refinancing) of the less interesting projects.

This analysis, which promotes the disciplinary aspects (of control and incentive), is unable to integrate the cognitive aspect of the creation of organizational capital. On the contrary, the works of O'Sullivan, 2001) focusing on the CG of innovative companies and the more ambitious works of Aoki can be considered, to some extent, as approximations to a study to build a theory of corporate governance where disciplinary aspects and cognitive acting simultaneously.

\section{Stewardship Theory or Management Theory}

Known as Management Theory (Donaldson, 2008). In it, it is considered that there is no conflict of interest between the owners and the managers and that it seeks to find an organizational structure that allows coordination to achieve greater efficiency. Managers are non-opportunistic agents, according to this theory, but good managers (Donaldson and Davis, 1991).

Given the limitations raised and as a reaction to the agency theory, at the beginning of the nineties, the "management theory" stewardship) emerged (Donaldson and Davis 1991; Davis, Schoorman, and Donaldson, 1997), under a vision psycho-sociological of corporate governance. This theory considers managers as good servants of the organization, assumes that professional managers of any company want to do a good job and will act as effective managers of its resources.

This explanation does not imply that the manager lacks personal objectives, but, on the contrary, is aware of the relationship that exists between his individual goals and the aims of the organization, and considers that the best way to achieve his purposes is work towards collective goals. However, it is considered that the stewardship theory has a limitation when studying the governance of companies and that is that it only takes into account the partners (owners of the company) and the steward (the manager), not paying no attention to the other interest groups (stakeholders) that affect or are affected more or less directly in society.

\footnotetext{
"Visión de Futuro" Año 18, Volumen No 25 N², Julio - Diciembre 2021 - Pág 178 - 194

URL de la Revista: http://visiondefuturo.fce.unam.edu.ar/index.php/visiondefuturo/index

URL del Documento: https://visiondefuturo.fce.unam.edu.ar/index.php/visiondefuturo/issue/view/21

ISSN 1668 - 8708 - Versión en Línea

E-mail: revistacientifica@fce.unam.edu.ar
} 
Managers are not motivated by individual goals, but rather are managers whose motives are aligned with the objectives of their principals (Davis, Schoorman, \& Donaldson, 1997). Organizational managers tend to be benign in their actions (Donaldson, 2008). Stewardship theory is a theory that indicates that if managers are left to their own devices, they will act as responsible managers of the assets they control (Hilb, 2005).

This theory assumes that long-term contractual relationships develop based on trust, reputation, collective goals, and participation, where the alignment of interests is a result that derives from relational reciprocity (Van Slyke, 2006). The interests of the managers are aligned with those of the shareholders, there is no conflict of interest that must be overcome with mechanisms such as financial incentives (Donaldson, 2008). Directors must recognize the interests of legitimate customers, employees, suppliers and other stakeholders, but under the law their first responsibility is to shareholders. Conflicts of interest between stakeholder groups and the company must be resolved by the pressure of competition in free markets, supported by legislation and existing legal controls to protect customers, employees, suppliers and society (Tricker, 2009).

\section{Analysis of theories in general}

In 2004, Gérard Charreaux concluded that the objective of corporate governance theories is not to study how managers govern, but rather how they are governed. This perspective is closer to the concept of control than to the concept of management (de AndrésAlonso and Santamaría-Mariscal, 2010).

Table 2. Analysis of GC theories

\begin{tabular}{|c|c|c|c|}
\hline Name & Autor & Year & Description \\
\hline Agency theory & $\begin{array}{l}\text { Adam } \\
\text { Smith }\end{array}$ & 1776 & $\begin{array}{l}\text { The managers of other people's money do not take } \\
\text { the same care as the owner. }\end{array}$ \\
\hline $\begin{array}{l}\text { Shareholder or } \\
\text { stockholder theory }\end{array}$ & Friedman & 1962 & $\begin{array}{l}\text { The only social responsibility of companies is to } \\
\text { minimize costs and maximize profits within the } \\
\text { rules of free enterprise. }\end{array}$ \\
\hline $\begin{array}{l}\text { The resource } \\
\text { dependency theory }\end{array}$ & $\begin{array}{l}\text { Pfeffer, } \\
\text { Salancik }\end{array}$ & 1978 & $\begin{array}{l}\text { Interpret organizations as interdependent on the } \\
\text { context in which they operate. }\end{array}$ \\
\hline Stakeholder theory & Freeman & 1984 & $\begin{array}{l}\text { The organization must be developed taking into } \\
\text { account the interests of the main interest groups, } \\
\text { without contradicting the ethical principles on which } \\
\text { capitalism is based. }\end{array}$ \\
\hline $\begin{array}{l}\text { Stewardship Theory } \\
\text { or Management } \\
\text { Theory }\end{array}$ & Donaldson & 1990 & $\begin{array}{l}\text { There is no conflict of interest between owners and } \\
\text { managers and an organizational structure is sought } \\
\text { that allows coordination to achieve greater } \\
\text { efficiency. }\end{array}$ \\
\hline $\begin{array}{l}\text { Knowledge-based } \\
\text { approach }\end{array}$ & Aoki & 2001 & $\begin{array}{l}\text { Build a theory of corporate governance where } \\
\text { disciplinary and cognitive aspects act } \\
\text { simultaneously. }\end{array}$ \\
\hline
\end{tabular}

Source: Prepared by the author based on related authors.

\footnotetext{
"Visión de Futuro" Año 18, Volumen No 25 N², Julio - Diciembre 2021 - Pág 178 - 194

URL de la Revista: http://visiondefuturo.fce.unam.edu.ar/index.php/visiondefuturo/index

URL del Documento: https://visiondefuturo.fce.unam.edu.ar/index.php/visiondefuturo/issue/view/21

ISSN 1668 - 8708 - Versión en Línea

E-mail: revistacientifica@fce.unam.edu.ar
} 
The main theory that has affected the development of corporate governance and has provided a conceptual framework for it is the agency theory. However, companies are increasingly aware that they cannot operate in isolation and that, in addition to considering shareholders, they must take into account a broad set of stakeholders (Mallin, 2010).

Referring to the first theory called agency theory, he points out that managers of other people's money do not take the same care as the owner himself, the second focuses on the fact that social responsibility should fall directly on people, and not on institutions, that is That is, it establishes that social responsibility does not correspond in any case to an obligation for the company, nor a benefit for it, in the third it is postulated that the organization must be developed taking into account the interests of the main interested parties (employees, clients, suppliers and creditors) without contradicting the ethical principles on which capitalism is based and the stewardship theory known as Management Theory. In it, it is considered that there is no conflict of interest between the owners and the managers and that the aim is to find an organizational structure that allows coordination to achieve greater efficiency.

The agency theory refers to an existing relationship that arises between two parties: on the one hand, there is the managerial level that includes the executives of the company; and the owners as directors and shareholders on the other hand according to the study by Jensen and Meckling (1976) and with the agreement of later studies (Tate, Ellram, Bals, Hartmann, and Valk, 2010). They argue that this relationship is based on implicit and explicit contractual conditions to ensure that all parties can operate as efficiently as possible for owners to maximize their wealth by delegating authority and assigning certain activities to the management level of a company. company, as the owners are not sufficiently trained to manage and undertake the required tasks. Therefore, the agency theory and its hypotheses have an effect on Corporate Governance Tirole (2010) supported this position by showing that generalized academic thinking about CG is due to the prevalence of research that is based on the premise of the underlying principle that agency theory focuses on the problem of the issue of separation between the management of a company and its property. In the first study conducted by Berle and Means in 1932 in the United States, there is a great deviation in the interests of managers and owners and therefore their motivations differ. It is a widely held view that effective QA mechanisms can reduce agency costs and therefore benefit shareholders.

\section{Corporate Governance and company performance}

According to Chen et al. (2009), recent empirical evidence in the literature demonstrates the ability of QA to limit agency cost, and this is in line with the view that, with improved levels of $Q A$, the firm improves performance as well as value. of the company.

\footnotetext{
“Visión de Futuro" Año 18, Volumen No 25 N², Julio - Diciembre 2021 - Pág 178 - 194

URL de la Revista: http://visiondefuturo.fce.unam.edu.ar/index.php/visiondefuturo/index

URL del Documento: https://visiondefuturo.fce.unam.edu.ar/index.php/visiondefuturo/issue/view/21

ISSN 1668 - 8708 - Versión en Línea

E-mail: revistacientifica@fce.unam.edu.ar
} 
A large body of literature published in recent decades has examined the performance of companies and their value. The literature highlights the existence of relationships that are linked to the mechanisms of the CG system and the multiplicity of points of view that lead to different results observed from these relationships. Despite the fact that studies have been carried out in different parts of the world, the literature supports the notion that QA is crucial, and positive, and has a significant relationship with the performance of a company. Agency theory has given significant importance to the application of the mechanisms and principles of $\mathrm{QA}$, since one of the main objectives of $\mathrm{QA}$ is an extension of agency. Tawfeeq and Alabdullah, (2016).

The purpose of the theory is to provide a solution to the eternal problem of conflict between shareholders and the management level of a company. The GC application has been caused by pressure. from an awareness and a real desire of internal stakeholders, such as shareholders, and external stakeholders, such as members of society, including customers, consumers and suppliers. The CG is a source of great interest around the world, as it is a useful tool to reduce or mitigate any business crisis, on the one hand, and on the other hand, the CG can be used as a basic component for companies to maximize their value by creating a competitive advantage, allowing them to improve their performance and, therefore, lead to an overall improvement in the economy of a country. Tawfeeq and Alabdullah, (2016).

\section{CONCLUSIONS}

Despite increased awareness and interest in corporate governance (CG) since the early 2000 s, the use of CG principles dates back hundreds of years to the 1600 s, although there was no direct application in At that time, it had neither been given a specific name or a law or legislative requirement that led to an application of the concept in business. In addition to the examination of agency theory, significant importance has been attached to the application of QA mechanisms and principles, as one of the main goals of QA is an extension of agency.

The wide range of literature reflects the strong diversity of ways of theoretically embroidering GC. Contrary to what the term corporate governance, however ambiguous, sometimes leads us to conclude, the objective of CG theories is not to study how managers govern - that would lead us to confuse the term governance with administration - but more well how they are governed.

Starting from the financial model based on the protection of shareholders' interests, corporate governance theories have evolved towards more complex models that involve all stakeholder groups and attach greater importance to the productive / cognitive aspects of the

\footnotetext{
“Visión de Futuro" Año 18, Volumen No 25 N², Julio - Diciembre 2021 - Pág 178 - 194 URL de la Revista: http://visiondefuturo.fce.unam.edu.ar/index.php/visiondefuturo/index

URL del Documento: https://visiondefuturo.fce.unam.edu.ar/index.php/visiondefuturo/issue/view/21

ISSN 1668 - 8708 - Versión en Línea

E-mail: revistacientifica@fce.unam.edu.ar
} 
creation of value. This evolution, influenced by that of the theories of the company, leads to consider

To the increasingly significant human capital since the formation of the competition. The advantage appears to be primarily skill based. In some cases, the approach to corporate governance that is considered adequate will be aimed at establishing a set of relationships and conditions that privilege the participation of shareholders in the added value, over the rest of the actors and participants in the value chain of the company. In other cases, the corporate governance approach will take into account that those who contribute to its generation should participate in the distribution of this added value.

From a theoretical point of view, the literature that we have used to interpret the relationship between certain characteristics of companies, especially financial performance with the adoption of corporate governance, and other independent variables, has been based on the postulates of the theories presented. , such as Agency Theory (Smith, 1776), Shareholder or Stockholder Theory (Friedman, 1962), Stakeholders Theory (Fremann, 1984), Tewardship Theory (Donaldson, 1990) and other theories and are the shareholders (Charreaux and Desbrières, 1996; Hilb, 2005). The value creation process is limited by the corporate governance system (Charreaux and Desbrières, 1996).

Theories about corporate governance, Economics, Administration, Law, Sociology, and Psychology, among others, emerge from various disciplines. In this case we focus on some theories that emerged from the first two: Agency Theory (Economy); Shareholder Theory (Economics), Stakeholder Theory (Administration), the knowledge-based approach and the Stewardship Theory (Administration).

The purpose of corporate governance is to provide a solution to the eternal problem of conflict between shareholders and the management level of a company. The GC application has been caused by pressure. of an awareness and a real desire of internal and external stakeholders.

\section{REFERENCES}

Please refer to articles in Spanish Bibliography.

\section{BIBLIOGRAPHICAL ABSTRACT}

Please refer to articles Spanish Biographical abstract.

\footnotetext{
"Visión de Futuro" Año 18, Volumen $N^{\circ} 25$ No 2, Julio - Diciembre 2021 - Pág 178 - 194

URL de la Revista: http://visiondefuturo.fce.unam.edu.ar/index.php/visiondefuturo/index

URL del Documento: https://visiondefuturo.fce.unam.edu.ar/index.php/visiondefuturo/issue/view/21

ISSN 1668 - 8708 - Versión en Línea

E-mail: revistacientifica@fce.unam.edu.ar
} 